\title{
Rational Design of a siRNA Delivery System: ALOX5 and Cancer Stem Cells as Therapeutic Targets
}

Diana Rafael $^{1,2^{*}}$, Fernanda Andrade ${ }^{2,3^{*}}$, Sara Montero ${ }^{2}$, Petra Gener ${ }^{2,3}$, Joaquin Seras-Franzoso $^{2}$, Francesc Martínez ${ }^{2}$, Patricia González ${ }^{2,3}$, Helena Florindo ${ }^{1}$, Diego Arango ${ }^{4}$, Joan Sayós ${ }^{5}$, Ibane Abasolo ${ }^{2,3,6},{ }^{*}$ Mafalda Videira ${ }^{1, \mathrm{a}}$, and *Simó Schwartz Jr. ${ }^{2,3, \mathrm{~b}}$

${ }^{1}$ Research Institute for Medicines and Pharmaceutical Sciences, Faculdade de Farmácia, Universidade de Lisboa (iMed.ULisboa), Lisbon, Portugal

${ }^{2}$ Drug Delivery and Targeting Group, Molecular Biology and Biochemistry Research Centre for Nanomedicine (CIBBIM-Nanomedicine), Vall d'Hebron Institut de Recerca, Universitat Autònoma de Barcelona, Barcelona, Spain

${ }^{3}$ Networking Research Centre for Bioengineering, Biomaterials, and Nanomedicine (CIBER-BBN), Instituto de Salud Carlos III, Zaragoza, Spain

${ }^{4}$ Biomedical Research in Digestive Tract Tumors, CIBBIM-Nanomedicine, Vall d'Hebron Institut de Recerca, Universitat Autònoma de Barcelona, Barcelona, Spain

Immune Regulation and Immunotherapy, CIBBIM-Nanomedicine, Vall d'Hebron Institut de Recerca, Universitat Autònoma de Barcelona, Barcelona, Spain

${ }^{6}$ Functional Validation \& Preclinical Research (FVPR), CIBBIM-Nanomedicine, Vall d'Hebron Institut de Recerca, Universitat Autònoma de Barcelona, Barcelona, Spain

*These authors contributed equally to this work.

Submitted: June 22, 2018;

Accepted: June 29, 2018;

Posted July 13, 2018

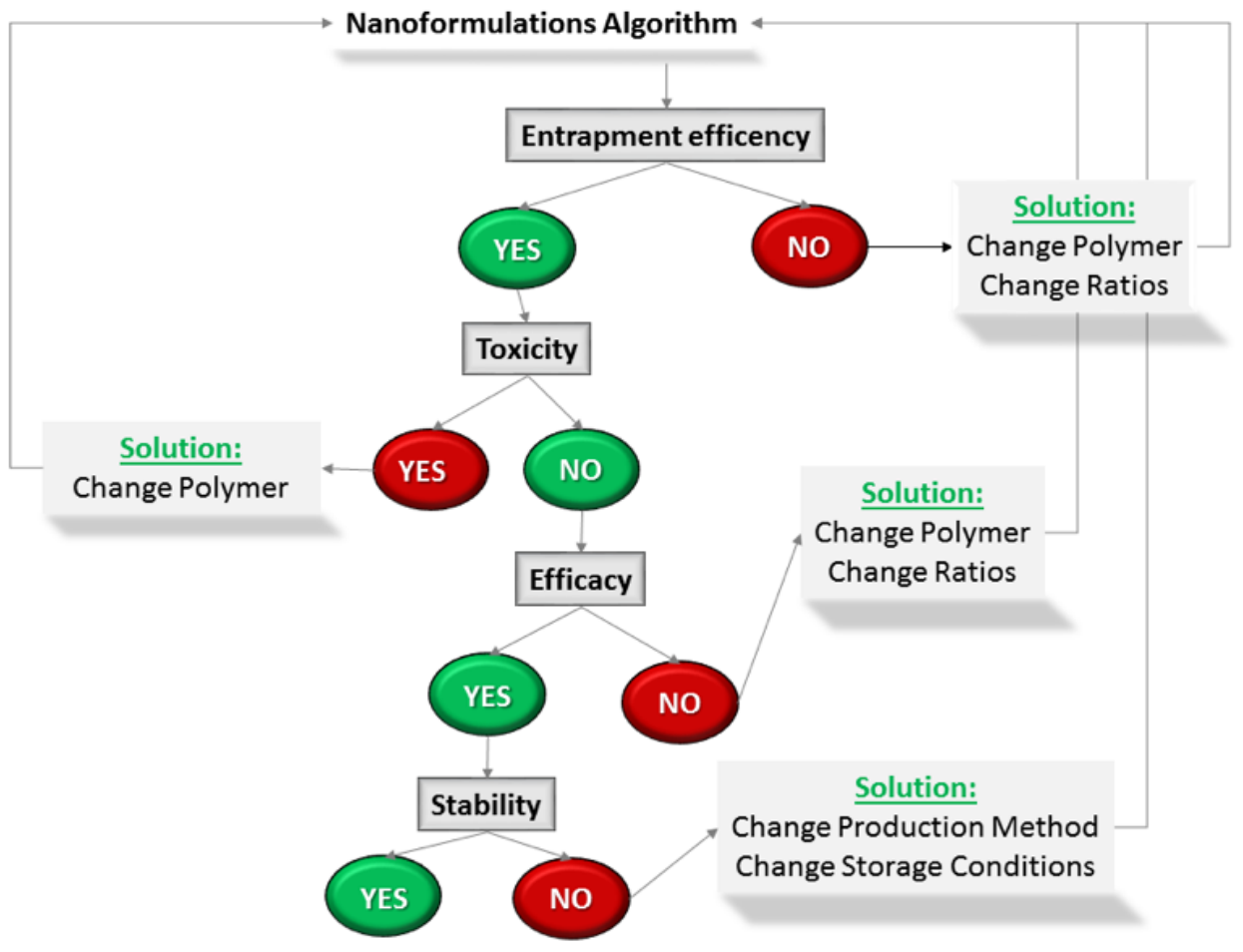

\footnotetext{
${ }^{a}$ Mafalda Ascensão Videira, PhD, Assistant Professor of Pharmaceutics, iMed.ULisboa Research Institute for Medicines. Pharmacological and Regulatory Sciences Group (PharmaRegSci), Faculdade de Farmácia da Universidade de Lisboa, Av. Prof. Gama Pinto, 1649-003 Lisboa, Portugal, mafaldavideira@campus.ul.pt ${ }^{\mathrm{b}}$ Simó Schwartz Jr, MD, PhD, Director, Molecular Biology and Biochemistry Research Center for Nanomedicine (CIBBIM-Nanomedicine), Vall d'Hebron Institut de Recerca (VHIR), Barcelona Vall d'Hebron Hospital Campus. Passeig de la Vall d'Hebron, 119-129 - 08035 Barcelona, Spain, simo.schwartz@,vhir.org
} 
Abbreviations:

- ALOX5 Arachidonate 5-lipoxygenase

- 5-DTAF 5-8[4,6-dichlorotriazin-2-yl]amino)fluorescein hydrochloride

- $\mathrm{AE}$

- ALDH1A1

Association efficiency

- CMT

Aldehyde dehydrogenase 1

- DAPI

Critical micellar temperature

- DD

4',6-diamidino-2-phenylindole

- DLS

Degree of deacetylation

- $\mathrm{DM}$

Dynamic light scattering

- EO

- EPR

- ERK

- FACS

- FBS

- FGFR

- $\mathrm{FH}$

- GADPH

Direct Dissolution method

- GFP

- MTT

Ethylene oxide

- PDI

- $\mathrm{PO}$

- qRT-PCR

- ZP

Enhanced permeability and retention effect

Extracellular signal-regulated kinases

Fluorescence-activated cell sorting

Fetal bovine serum

Fibroblast growth factor receptors

Thin-film hydration

Glyceraldehyde 3-phosphate dehydrogenase

Green fluorescent protein

3-(4,5-dimethythiazol-2-yl)-2,5 diphenyl tetrazolium bromide

Polydispersity index

Propylene oxide

Quantitative real time polymerase chain reaction

Zeta potential

Keywords:

Polymeric Micelles, Pluronic ${ }^{\circledR}$ F127, Gene Delivery, siRNA, ALOX5, Cancer Stem Cells.

\section{Abstract}

The search for an ideal gene delivery system is a long and laborious process in which several factors from the first idea to final formulation, including main challenges, peaks and troughs, should be deeply taken into consideration to ensure adequate biological safety and in vivo efficacy endpoints. Arachidonate 5-lipoxygenase (ALOX5), a crucial player related with cancer development and in particular with cancer stem cells malignancy. In this work we describe the process behind the development of a small interfering RNA (siRNA) delivery system to inhibit ALOX5 in cancer stem cells (CSC), as a model target gene. We started by screening chitosan polyplexes, among different types of chitosan in different complexation conditions. Due to the low silencing efficacy obtained, chitosan polyplexes were combined with Pluronic ${ }^{\circledR}$-based polymeric micelles with recognized advantages regarding gene transfection. We tested different types of polymeric particles to improve the biological efficacy of chitosan polyplexes. Nevertheless, limited transfection efficiency was still detected. The well-established polyethylenimine (PEI) cationic polymer was used in substitution of chitosan, in

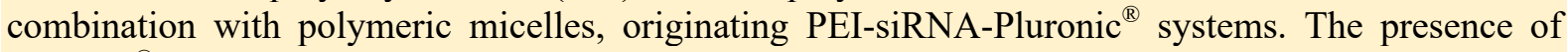
Pluronic ${ }^{\circledR}$ F127 in the formulation showed to be of utmost importance, because not only the silencing activity of the polyplexes was improved, but also PEI-associated toxicity was clearly reduced. This, allowed to increase the amount of PEI inside the system and its overall efficacy. Indeed, different types of PEI, N/P ratios and preparation methods were tested until an optimal formulation composed by PEI $10 \mathrm{k}$ branched-based polyplexes at an N/P ratio of 50 combined with micelles of Pluronic ${ }^{\circledR} \mathrm{F} 127$ was selected. This combined micelle presented adequate technological properties, safety profile and biological efficacy, resulting in high ALOX5 gene silencing and strong reduction of invasion and transformation capabilities of a stem cell subpopulation isolated from MDA-MB-231 triple negative breast cancer cells. 


\section{Rationale and Purpose}

The design and development of a nanoparticlebased drug delivery system is a long and complex process that is often not reflected in the literature. There are years of backstage work and a wide collection of negative results that are considered not publishable. However, this data gives crucial information for moving forward in the proper direction. Moreover, the publication of negative results, although not usual, is of great importance for time and resources optimization, by avoiding the repetition of similar errors by other research groups and, more importantly, by redefining the work plan priorities. Described in this work is the rational design and experimental sequence beyond the development of a nanocarrier system for siRNA intracellular delivery, with the negative results and the consequent modifications and improvements. The ultimate goal is the development of a new nanotechnology-based approach for cancer treatment.

\section{Introduction}

Despite of considerable number of advances achieved in the past decades, clinical use of nucleic acids as gene-based antitumor therapy is still precluded, mainly because of their poor cellular uptake, vulnerability to enzymatic degradation, and rapid renal clearance. Until now, most gene therapy strategies rely on the use of viral vectors, even though their use frequently raises important safety issues, challenging their clinical standardization as gene delivery vectors. Further, several limitations have also been identified in some non-viral vectors, such as low specificity, cellular toxicity, and limited transfection efficiencies (1, 2). Therefore, successful clinical application of gene therapy in the oncology field urgently demands the emergence of new and safer vehicles to first, enable oligonucleotides (OGN) to be effectively delivered into tumor target cells, and second, to overcome the well-known drawbacks of current vehicles (1, 3-6). Moreover, the design of a new vehicle has to take into account that an ideal gene delivery system should be efficient, stable, cost effective, and able to avoid rapid hepatic and renal clearance. Safety issues such as biocompatibility, biodegradability and lack of immunogenicity are also critical, as well as the need of an appropriate balance between protection and release of the genetic material from the endosomes (e.g. proton-sponge effect) in order to ensure biological functionality $(1,7)$. Other characteristics such as particle size, surface charge, presence of moieties and also their interactions with the tumoral environment should be finely tuned in order to improve their biological behavior and efficacy $(8,9)$. Nanoparticles intended for gene delivery usually possess in its composition cationic polymers, such as chitosan (CS) and polyethylenimine (PEI) that condense negatively charged nucleic acids through electrostatic interactions $(2,10,11)$.

$\mathrm{CS}$ is a natural cationic polysaccharide composed of glucosamine and N-acetyl glucosamine, whose ability to interact with negatively charged OGN depend, among other factors, on its Molecular Weight (MW) and Deacetylation Degree (DD). Whereas high DD enables better interaction with genetic material, high MW improves stability of the complexes, while low MW ameliorates intracellular release of OGN (12-14). Accordingly, DD and MW of CS should be adequately considered in order to ensure an appropriate balance between protection and release of OGN. In order to improve transfection efficiency of CS-based carriers, different chemical modifications as well as the use of the water-soluble salt forms of CS have been investigated (12,13, 15-21). Regarding PEI and despite its high transfection efficiency, its use as a delivery vehicle is hampered because of its high cationic charge density (22-24). In fact, the transfection efficiency and cytotoxicity of these polymers are highly dependent on their linear versus branched structure, their branching degree and their MW (23, 25-28). PEI branched forms present higher transfection efficiencies than linear forms. Furthermore, higher MW PEI are frequently associated with higher buffering capacity, higher transfection efficiencies and also with increased cytotoxicity. An adequate ratio between the nitrogen content of the polymer and the number of phosphate groups from the OGN (N/P ratio) should be optimized for each formulation in order to find an equilibrium of charges and to achieve maximal efficacy with minor toxicity $(23,25,27,29)$. 
Many different strategies have been explored in order to improve the efficiency of PEI transfection by reducing cytotoxicity, avoiding aggregation, and decreasing nonspecific interactions. Among them, grafting PEI with polyethylenglycol (PEG) has become one of the most popular ones $(30,31)$.

In this study, both CS and PEI polycations have been used in combination with poloxamers $\left(\right.$ Pluronic $^{\circledR}$ ) based micelles (PM) in order to achieve an improvement of their transfection efficiency and toxicity profile, as well as their efficacy against cancer cells. Poloxamers are amphiphilic polymers consisting in ethylene oxide (EO) and propylene oxide (PO) chains arranged in an $a-b-a$ triblock structure (EO-POEO) $(32,33)$. They have been included in the formulation due to their recognized ability to enhance transfection of genetic material (3336). Because of their PEGylated surface, poloxamers offer stealth properties to the system and can be easily functionalized with different targeting moieties (37). Moreover, these polymers are approved for human administration due to their optimal watersolubility, biodegradability, and biocompatibility, as well as their low immunogenicity profile, which makes them a simple and safer approach for in vitro and in vivo gene transfection $(38,39)$. Several conditions and combinations have been tested to better define those which show the highest transfection efficiency and good antitumor efficacy in bioluminescent breast cancer models. Indeed, among the big challenges in cancer therapy are the avoidance of the metastatic spread of the disease, the appearance of multidrug resistance, and tumor recurrence as those features which are mostly related to the presence of CSC within a tumor (40). Arachidonate 5lipoxygenase (ALOX5) silencing was selected as a candidate target due to its recognized key role in CSC survival and self-renewal (41). Our data show that poloxamer-PEI combinations with ALOX5-siRNA were effective in silencing ALOX5 in breast CSC and showed great therapeutic potential as anticancer treatment, significantly reducing cell malignant transformation and CSC invasion.

\section{Materials and Methods}

\section{Materials}

Different types of CS with DD of $\sim 86 \%$ (Protasan Ultrapure) were gently provided by NovaMatriX (USA), namely, glutamate-CS low (G113 - $160 \mathrm{kDa})$ and high (G213 - 470 $\mathrm{kDa}) \mathrm{MW}$, and hydrochloride-CS low (CL113 - $110 \mathrm{kDa}$ ) and high (CL213 - $270 \mathrm{kDa}$ ) MW. Glycol-CS was purchased from Sigma Aldrich (Madrid, Spain). Pluronic ${ }^{\circledR}$ F68, F108 and F127 were kindly provided by BASF (Ludwigshafen, Germany), while $10 \mathrm{k}$ branched and $25 \mathrm{k}$ branched PEI were provided by Alfa Aesar (Thermo Fisher GmbH, Karlsruhe, Germany) and Sigma-Aldrich (Madrid, Spain), respectively. siRNA against gree fluorescent protein (GFP-siRNA) and the scramble sequence (siC) were provided by LifeTechnologies (Spain). The sense antiALOX5 siRNA sequence used was 5'CUGAGCGCAACAAGAAGAATT-3', while a non-specific sequence, 5'UUCUCCGAACGUGUCACGUTT-3', was used as negative control. MDA-MB-231 (ATCC number HTB-26) cell line was obtained from American Type Culture Collection (ATCC, LGC Standards, Barcelona, Spain), and $\mathrm{RXO}-\mathrm{C}$ colon cancer cells expressing GFP were generously provided by Dr. Diego Arango (CIBBIM-Nanomedicine). RPMI medium, phosphate buffered saline (PBS), and fetal bovine serum (FBS) were purchase from Lonza (Barcelona, Spain). Penicillin-streptomycin, Lglutamine, non-essential amino acids, sodium pyruvate, $\quad 0.25 \% \quad$ Trypsin-EDTA, Lipofectamine $^{\circledR} \quad 2000, \quad$ 4',6-diamidino-2phenylindole (DAPI), and LysoTracker ${ }^{\circledR}$ Red were brought from Life Technologies Ltd. (Madrid, Spain). Other reagents used were methanol, ethanol, dimethyl sulfoxide (DMSO), 3-(4,5-dimethythiazol-2-yl)-2,5diphenyl tetrazolium bromide (MTT), gelatin, paraformaldehyde, Triton X-100, and 5-([4,6dichlorotriazin-2-yl]amino)fluorescein hydrochloride (5-DTAF) from Sigma-Aldrich (Madrid, Spain), and Type 1 ultrapure water (18.2 M .cm at $25^{\circ} \mathrm{C}$, Milli-Q ${ }^{\circledR}$, Billerica, MA, USA).

\section{Methods}

\section{Polyplex Preparation}

Polymer-siRNA complexes were prepared by simple complexation, adding the polymer 
solution dropwise to an equal volume of siRNA solution. The mixture was quickly vortexed during few seconds and incubated at room temperature for 30 minutes. CS-siRNA complexes were prepared at different $\mathrm{N} / \mathrm{P}$ ratios calculated according to Equation 1 (mass per charge of phosphate $=330 \mathrm{~g} / \mathrm{mol}$ and mass per charge of Nitrogen $=160 \mathrm{~g} / \mathrm{mol}$ ) and at different conditions (Table 2).

$$
\begin{aligned}
& \frac{\mathrm{N}}{\mathrm{P}} \text { ratio }=\frac{\frac{\text { Mass of polycation }}{\text { Mass per charge of Nitrogen }}}{\frac{\text { Mass of siRNA }}{\text { Mass per charge of Phosphate }}} \\
& \text { Equation } 1
\end{aligned}
$$

For the PEI-based polyplexes, two types of branched PEI, namely $10 \mathrm{k}$ and $25 \mathrm{k}$, were used. Different N/P ratios were tested ranging from 5 to 75 (Table 4) and calculated according to Equation 1 (Considering mass per charge of phosphate $=330 \mathrm{~g} / \mathrm{mol}$ and mass per charge of nitrogen $=43 \mathrm{~g} / \mathrm{mol}$ ).

\section{Micelles Preparation through the Direct Dissolution Method (DM)}

The amphiphilic polymer was dissolved overnight $(\mathrm{O} / \mathrm{N})$ under agitation in aqueous solution, and added dropwise to the polyplexes solution, previously prepared. After vortexing, the mixture was left to incubate for 30 minutes and filtered through a $0.22 \mu \mathrm{m}$ syringe filter.

\section{Micelles Preparation through the Thin- \\ Film Hydration (FH) Technique}

The amphiphilic polymers were individually weighted and dissolved in a mixture of methanol:ethanol $=1: 1$. This mixture of solvents was chosen because the polymers are insoluble in ethanol alone (Class 3 solvent), but soluble in methanol (Class 2 solvent). By mixing both solvents it was possible to solubilize the polymers and reduce the use of methanol, as previously described. Then, the solvent was removed under vacuum and the formed film was left to dry at room temperature to eliminate any remaining solvent. Afterwards, the film was hydrated with PBS for empty micelles or with the previously prepared polymer-siRNA polyplexes and vortexed for 1 minute. The obtained dispersion was filtered through a 0.22 $\mu \mathrm{m}$ syringe filter to remove possible aggregates.

\section{Association Efficiency (AE)}

The non-associated siRNA present in the aqueous phase of the polyplexes was separated by centrifugation with filtration $(10,000 \mathrm{rpm}$, 10 minutes) using a $100 \mathrm{~K}$ membrane Nanosep $^{\circledR}$ Centrifugal Devices, Millipore, USA) and measured by spectrophotometry (Nanodrop NP-1000, Thermo Scientific, USA). AE was calculated according to Equation 2, and also assessed by agarose gel electrophoresis. Polyplexes were loaded onto $1 \%$ agarose gel with $6 \mathrm{X}$ loading buffer. The mixture was separated in $0.5 \mathrm{X}$ Tris/Borate/EDTA (TBE) buffer at $100 \mathrm{~V}$ for 25 minutes. siRNA bands were visualized using an ultra violet imaging system (Uvidoc, UVItec Ltd, Cambridge, UK).

$\mathrm{AE}=\frac{\text { Total amount of SiRNA-Free siRNA in filtrate }}{\text { Total amount of SiRNA }} \times 100$

Equation 2

Particles Physicochemical Characterization Particles mean hydrodynamic diameter (md) and polydispersity index (PDI) were measured by dynamic light scattering (DLS). Zeta potential was assessed by laser Doppler microelectrophoresis using NanoZS (Malvern Instruments, UK). For each formulation, at least three batches were produced and analyzed. Particle shape and morphology were observed by transmission electron microscopy (external services from IBMC, University of Porto, Portugal).

\section{Serum Stability}

To assess the stability of formulations in the presence of serum, particles were incubated in a proportion of $1: 1$ with $50 \%$ FBS culture medium. Mean diameter was measured by DLS at $0,6,12$, and 24 hours.

\section{Cell Lines Culture Conditions}

RXO-C and MDA-MB-231 breast cancer cell lines were cultured in RPMI medium supplemented with $10 \%$ FBS, $1 \%$ penicillinstreptomycin, $1 \%$ L-glutamine, $1 \%$ nonessential amino acids and $1 \%$ of sodium pyruvate. CSC subpopulation from MDA-MB231 cell line was isolated using a model previously validated by our group (42). Briefly, the model is based on the expression of tdTomato under the control of a CSC specific promoter (ALDH1A1), which allows the separation of CSC among the bulk tumor cells population and the study of the biological 
efficacy of the developed therapeutic system in this subpopulation of cells. Blasticidin ( 0.5 $\mathrm{mg} / \mathrm{mL}$ ) was used as a selective antibiotic for ALDH1A1/tdTomato cell lines. All cell lines were kept at $37^{\circ} \mathrm{C}$ under $5 \% \mathrm{CO}_{2}$ saturated atmosphere. Cell medium was changed every other day and, upon confluence, cells were harvested from plates with $0.25 \%$ trypsinEDTA

\section{Cell Transfection}

Different siRNA formulations were transfected into cells according to the conditions shown in Table 1. For silencing experiments, the medium was changed after 4 hours of incubation with polyplexes and PM-polyplexes. For the toxicity assays, cells were left 24 hours in contact with formulations, while for internalization assays, cells were incubated over 4 hours. Cells were harvested 24 to 72 hours after transfection. For internalization experiments, particles were diluted at a ratio of 1:10. Lipofectamine ${ }^{\circledR} 2000$ was used as positive control for transfection according to suppliers' protocols and in order to obtain a final siRNA concentration in the well of $200 \mathrm{nM}$. For all experiments, cells were transfected at the same conditions using a scrambled siRNA sequence ( $\mathrm{siC})$.

Table 1. Transfection Conditions for the Different Experiments

\begin{tabular}{|c|c|c|c|c|c|}
\hline & \multicolumn{2}{|c|}{ Day 0: before transfection } & \multicolumn{2}{c|}{ Day 1: during transfection time (4 hours) } \\
\hline Plates & $\begin{array}{c}\text { Cells seeded } \\
(\text { cells/well })\end{array}$ & $\begin{array}{c}\text { Volume of medium } \\
(\mu \mathrm{l})\end{array}$ & $\begin{array}{c}\text { Volume of } \\
\text { medium } \\
(\mu \mathrm{l})\end{array}$ & $\begin{array}{c}\text { Volume of } \\
\text { formulation } \\
(\mu \mathrm{l})\end{array}$ & $\begin{array}{c}\text { Final siRNA } \\
\text { concentration } \\
(\mathrm{nM})\end{array}$ \\
\hline 96 well & $5.0 \times 10^{3}$ & 100 & 50 & 50 & 200 \\
\hline 24 well & $5.0 \times 10^{4}$ & 1000 & 100 & 100 & 200 \\
\hline 6 well & $2.0 \times 10^{5}$ & 2000 & 250 & 250 & 200 \\
\hline
\end{tabular}

\section{GFP Reporter Gene Silencing Assay}

RXO-C cancer cells expressing GFP were used as a model to assess the silencing efficacy of the different nanosystems. Polyplexes and micelles prepared using a GFP-siRNA and different cationic polymers were transfected to cells previously seeded in 96 well plates. Complexes formed between Lipofectamine ${ }^{\circledR} 2000$ and GFP-siRNA were used as positive controls. The expression of GFP in cells after transfection was assessed with fluorescence microscopy (Olympus, USA). The intensity of cells fluorescence was also measured using an FLX800 Fluorescent Microplate Reader (BioTek, Germany).

\section{In vitro Cytotoxicity Assay}

The cytotoxicity of different components was assessed in MDA-MB-231 breast cancer cells using the MTT assay. Briefly, cells previously seeded in 96-well plates were incubated in the presence and absence of increasing concentrations of polymers/formulations for 24 hours. After the incubation time, medium was changed, and cells left for additional 72 hours. Complete medium was used as negative control and $10 \%$ DMSO as positive control of toxicity.
After 72 hours of incubation, $0.5 \mathrm{mg} / \mathrm{mL}$ of MTT was added to each well. Plates were incubated for additional 4 hours at $37^{\circ} \mathrm{C}$, the medium discarded, and the formazan crystals produced by mitochondrial succinate dehydrogenase dissolved with DMSO. The absorbance of each well was read on a microplate reader (ELx800 absorbance reader, BioTek, Germany) at $590 \mathrm{~nm}$ and cell viability calculated accordingly. Cell viability data were used to determine $\mathrm{IC}_{50}$ value by nonlinear regression of the dose-effect curve fit, using Prism 6.02 software (GraphPad Software, Inc., CA, USA).

\section{Conjugation of F127 with 5-DTAF}

F127 was fluorescently conjugated with 5DTAF in an aqueous medium via nucleophilic aromatic substitution by an additionelimination pathway, as previously described. ${ }^{44}$ Briefly, a stock solution of $20 \mathrm{~g} / \mathrm{L}$ 5-DTAF in DMSO was diluted in $0.1 \mathrm{M}$ sodium bicarbonate (pH 9.3) and added to a $6 \%(\mathrm{w} / \mathrm{v})$ F127 solution in $0.1 \mathrm{M}$ sodium bicarbonate ( $\mathrm{pH}$ 9.3) to a final molar ratio of 1:2 (F127:5-DTAF). The reaction was left overnight in the dark, at room temperature. Unreacted 5-DTAF was washed out by dialysis $(12,000-14,000$ MWCO 
Spectra/Por ${ }^{\circledR}$ membrane from Spectrum Europe BV, The Netherlands) against type I ultrapure water. Dialyzed polymer solutions were lyophilized and stored in closed containers protected from light (Virtis Benchtop Freeze Dryer, SP Scientific).

\section{Internalization Assays}

Flow cytometry and confocal microscopy were used to assess quantitatively and qualitatively the internalization capacity of the nanosystem into MDA-MB-231 breast cancer cells. For quantitative Fluorescence-activated cell sorting (FACS) assays, $2 \times 10^{5}$ cells were seeded in 6 well plates and incubated for 24 hours. After incubation, 5-DTAF-labelled micelles were added to cells and incubated for 4 hours, and washed with $1 \times$ PBS, detached with $0.25 \%$ trypsin-EDTA, and re-suspended in PBS supplemented with $10 \%$ FBS. Cells were then stained with DAPI $(1 \mu \mathrm{g} / \mathrm{mL})$. Plates were analyzed in a Fortessa cytometer (BD Biosciences, San Jose, California, USA). Data were analyzed with FCS Express 4 Flow Research Edition software (De Novo Software, Los Angeles, USA). Contaminants were removed by forward and side scatter gating. For each sample, at least 10000 individual cells were collected to measure mean fluorescence intensity. For qualitative confocal microscopy assay (Spectral Confocal Microscope MFV1000 Olympus, USA), cells were cultured in $0.1 \%$ gelatin-treated coverslips at a density of $2.5 \times 10^{5}$ cells per well in 6 well plates. After 24 hours, cells were incubated with 5-DTAF labelled-PM for 4 hours, and further incubated for 30 minutes with LysoTracker ${ }^{\circledR}$ Red. Subsequently, cells were fixed using $4 \%$ paraformaldehyde. Finally, nuclei were stained with DAPI $(0.2 \mathrm{mg} / \mathrm{mL})$ for 5 minutes in the dark and further visualized.

\section{Cell sorting}

FACS was used to sort CSC and non-CSC subpopulations from a heterogeneous population MDA-MB-231 cells. For cell sorting, a starting amount of $5 \times 10^{6}$ cells was used. Cells were detached with $0.25 \%$ trypsinEDTA and re-suspended in PBS supplemented with $10 \%$ FBS and DAPI $(1 \mu \mathrm{g} / \mathrm{mL})$ used for vital staining. Cells were sorted according to tdTomato expression and DAPI staining in a FACS Aria cell sorter (BD Biosciences, Madrid, Spain). Sorted cells were collected in complete medium without antibiotic and stored. $^{44}$

\section{RNA Extraction and Quantitative RT-PCR \\ (qRT-PCR)}

Total RNA was extracted from cells using RNeasy Micro Kit (Qiagen, Madrid, Spain). RNA was reverse transcribed with High Capacity cDNA Reverse Transcription Kit (Applied Biosystems, Madrid, Spain) according to manufacturer instructions. The cDNA reverse transcription product was amplified with specific primers for ALOX5 (hALOX5 F:

5' AGAACCTGGCCAACAAGATTGT A 3'; hALOX5 R:

5' TCTGGTGGACGTGGAAGTCA 3') GADPH (hGADPH F: 5' ACC CAC TCC TCC ACC TTT GAC; hGADPH R:

5' CAT ACC AGG AAA TGA GCT TGA CAA 3') and

Actin (hActin F:

5' CAT CCA CGA AAC TAC CTT CAA CTC C 3';

hActin R:

5'GAG CCG CCG ATC CAC AC 3') by qPCR using the SYBR Green method. The reaction was performed in triplicate in a 7500 Real-Time PCR system (Applied Biosystems, Madrid, Spain). Actin and GADPH, were used as endogenous controls. Relative mRNA levels were calculated using the comparative $\mathrm{Ct}$ method (2e- $\Delta \Delta \mathrm{Ct})$.

\section{Cell Transformation Assay (Anchorage- Independent Growth Assay)}

Anchorage-independent growth of the different breast cancer cell lines was assessed by CytoSelect $^{\mathrm{TM}}$ Cell Transformation Assay Kit (Cell Biolabs, San Diego, CA, USA). A semisolid agar media was prepared according to manufacturer prior addition of PM-siALOX5 or PM-siC to each well. After 6-8 days of incubation, colonies were observed under optical microscopy and viable transformed cells counted using trypan blue.

Invasion Assay

Cells invasiveness was assessed using CytoSelect ${ }^{\mathrm{TM}}$ Laminin Cell Invasion Assay Kit (Cell Biolabs, San Diego, CA, USA) accordingly to manufacturer instructions. Briefly, inserts were placed in 24 well plates 
and $2.5 \times 10^{4}$ cells previously transfected (24 hours before) with PM-siALOX5 and PM-siC, added to the upper chamber. After 48 hours incubation, invasive cells were dissociated from the membrane, lysed, and quantified with CyQuant $^{\circledR}$ GR Fluorescent Dye using an FLX800 Fluorescent Microplate Reader (BioTek, Germany).

\section{Statistical Analysis}

At least three batches from each polyplex and PM were produced and characterized, and results expressed as mean \pm standard deviation (SD). For biological studies, at least 3 replicates, each involving at least two technical replicates, were involved. Final results were also expressed as mean \pm SD. Statistical analysis was performed in Microsoft Office Excel ${ }^{\mathrm{TM}}$ 2010 using unpaired Student's t-test. Differences were considered as statistically significant when $\mathrm{p}$-values were smaller than 0.05 .

\section{Results}

\section{CS-Based Systems}

Due to known advantages of CS and its derivatives for gene delivery, a screening for the best CS polyplexes with optimal transfection conditions was performed. GFP silencing efficacy of different conditions and combinations were also tested (Table 2). For all $\mathrm{CS}$ showing high $\mathrm{AE}$ in vitro cytotoxicity was also assessed.

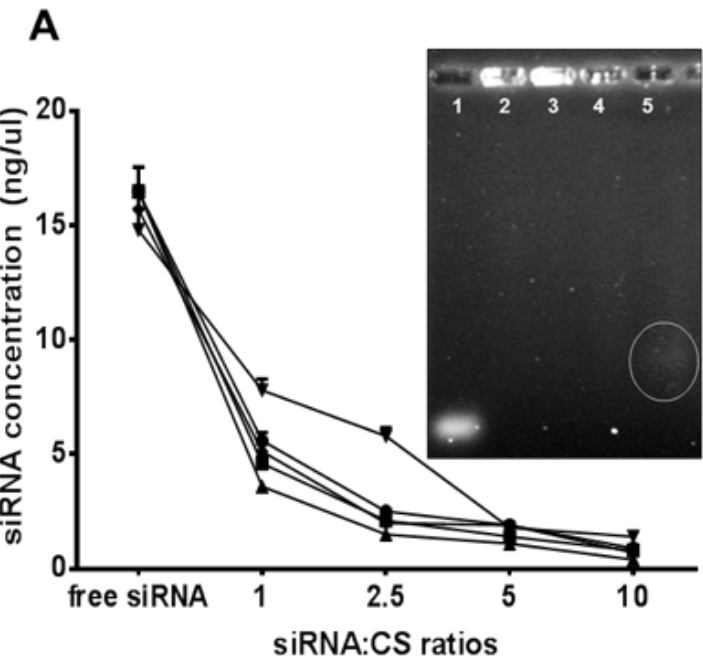

B

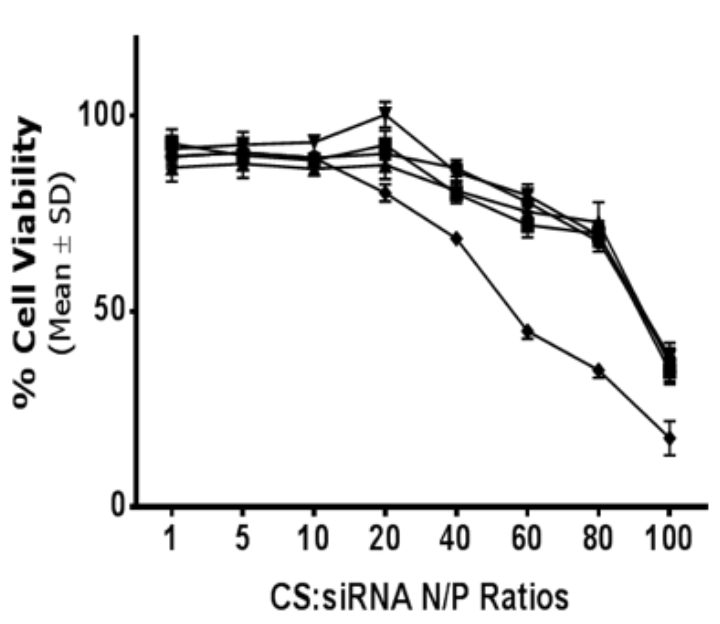

- CL113-CS

\section{G113-CS}

CL213-CS

* G213-CS — Glycol-CS

Figure 1. A, In vitro cytotoxicity of CS-siRNA polyplexes at different N/P ration in MDA-MB-231 cells. B, Polyplexes association efficiency. The graph represents the concentration of free siRNA detected in the supernatant by spectrophotometry after formulation filtration by centrifugation using different N/P ratios. Agarose gel electrophoresis for the CL213-based polyplex. 1 - free siRNA; 2 - 1:10 ratio; 3 - 1:5 ratio; 4 - 1:2.5 ratio; 5-1:1 ratio. Free siRNA was observed in siRNA:CS ratio of 5:1 (encircled).

According to our data, all CS were able to efficiently complex with siRNA (Figure 1A). A decrease in the concentration of free siRNA was observed upon complexation with CS even at low ratios. Additionally, in the agarose gel assay, a small amount of free siRNA was only detected in CS:siRNA 1:1 ratio. Nonetheless, low N/P ratios are not enough to produce biological efficacy, thus higher $\mathrm{N} / \mathrm{P}$ ratios were further tested in terms of cell toxicity. Figure 1B demonstrates that CL113, G113, CL213 and G213 have a similar toxicity pattern, being an $\mathrm{N} / \mathrm{P}$ ratio of 80 the maximum N/P ratio that can be used without causing severe toxicity. Glycol-CS causes higher toxicity even at lower $\mathrm{N} / \mathrm{P}$ ratios. 
Table 2. Summary of the Different Conditions Tested on CS-Based Polyplexes

\begin{tabular}{|c|c|c|}
\hline \multicolumn{2}{|r|}{ Tested Conditions } & Observations \\
\hline \multirow{3}{*}{$\begin{array}{l}\text { siRNA final conc. } \\
\text { in the well }\end{array}$} & $50 \mathrm{nM}$ & No effect \\
\hline & $100 \mathrm{nM}$ & No effect \\
\hline & $200 \mathrm{nM}$ & Effective (at certain conditions) \\
\hline \multirow{5}{*}{ Polyplexes } & Glycol-CS & Toxic (at ratios $>60)$ \\
\hline & G113 & No effect \\
\hline & CL113 & No effect \\
\hline & G213 & Effective (at certain conditions) \\
\hline & CL213 & Effective (at certain conditions) \\
\hline \multirow{8}{*}{$\mathrm{N} / \mathrm{P}$ ratios } & $<10$ & No effect \\
\hline & 20 & No effect \\
\hline & 30 & No effect \\
\hline & 40 & No effect \\
\hline & 60 & No effect \\
\hline & 80 & $\begin{array}{l}\text { Knockdown detected (at certain } \\
\text { toxicity) }\end{array}$ \\
\hline & 100 & Toxicity \\
\hline & $>100$ & Highly toxic \\
\hline \multirow{2}{*}{$\mathrm{pH}$} & 4.5 (in acetate buffer) & Higher efficacy \\
\hline & 7 (in water) & Low effect \\
\hline \multirow{3}{*}{ Time-points } & 24 hours & No effect \\
\hline & 48 hours & No effect \\
\hline & 72 hours & Knockdown detected \\
\hline Micelles & $\begin{array}{c}\text { CL213 (N/P 80, pH 4.5) + F127 (1\%) } \\
\text { Time-point } 72 \text { hours }\end{array}$ & Effect $<$ than Lipofectamine ${ }^{\circledR} 2000$ \\
\hline
\end{tabular}

As described in Table 2, the most promising polyplexes, such as those able to cause a visible decrease in the number of cells expressing GFP without promoting significant toxicity, were obtained with the following conditions: GFPsiRNA at a final concentration of $200 \mathrm{nM}$ per well, complexed with CL213 and G213 CS at a $\mathrm{N} / \mathrm{P}$ ratio of 80 and $\mathrm{pH} 4.5$, observed in a posttransfection incubation time of 72 hours.

Results depicting the silencing efficacy of CL213-based GFP-siRNA polyplexes produced at optimal conditions, are showed in Figure 2A. A partial silencing of the expression of GFP at 72 hours after transfection, was observed. Nonetheless, a significantly stronger silencing was observed in cells transfected with Lipofectamine $^{\circledR}$ 2000. On the contrary, no decrease of GFP expression was observed in cells transfected with siC. Similar results were obtained with the polyplexes composed by G213. No significant silencing efficacy was observed with other types of CS tested. CSsiRNA polyplexes produced with CL213-CS were further characterized resulting in $17 \mathrm{~nm}$ size, positive charge $(+15 \mathrm{mV})$ and spherical shape (Table 3).

Table 3. Physicochemical Characterization of Polyplexes using CL213 CS

\begin{tabular}{|l|l|}
\hline Parameters & CL113-CS polyplexes \\
\hline Md $(\mathrm{nm})$ & $16.6 \pm 0.8$ \\
\hline PDI & $0.19 \pm 0.07$ \\
\hline Zp $(\mathrm{mV})$ & $+15.2 \pm 1.7$ \\
\hline
\end{tabular}

$\mathrm{Md}=$ mean diameter; $\mathrm{PDI}=$ polydispersity index; $\mathrm{Zp}=$ Zeta potential. $\mathrm{Md}, \mathrm{PDI}$, and $\mathrm{Zp}$ values for Cs-siRNA polyplexes are expressed as mean $\pm \mathrm{SD}, \mathrm{n}=3$. 
Table 4. Physicochemical Characterization of Different Pluronic ${ }^{\circledR}$-Based Micelles

\begin{tabular}{|l|l|l|l|l|}
\hline Polymer & Md $(\mathrm{nm})$ & PDI & Zp $(\mathrm{mV})$ & $\mathrm{IC}_{50}(\mathrm{mg} / \mathrm{mL})$ \\
\hline F68 & $228.6 \pm 31.2$ & $0.5 \pm 0.2$ & $2.9 \pm 1.0$ & n.d. \\
\hline F108 & $130.2 \pm 18.4$ & $0.4 \pm 0.2$ & $2.1 \pm 1.2$ & $>10$ \\
\hline F127 & $68.5 \pm 9.4$ & $0.2 \pm 0.1$ & $2.7 \pm 1.8$ & $>10$ \\
\hline
\end{tabular}

$\mathrm{Md}=$ Mean diameter; $\mathrm{PDI}=$ polydispersity index; $\mathrm{Zp}=\mathrm{Zeta}$ potential. $\mathrm{Md}$, $\mathrm{PDI}$ and $\mathrm{Zp}$ values for polyplexes CssiRNA are expressed as mean $\pm \mathrm{SD}, \mathrm{n}=3$.

Different Pluronic ${ }^{\circledR}$-based PM obtained by direct DM were tested with the objective to ensure protection of the siRNA sequence and to increase the biological efficacy of these polyplexes. All micelles presented sizes under $250 \mathrm{~nm}$ (lower than $75 \mathrm{~nm}$ for Pluronic ${ }^{\circledR}$ F127) and nearly a neutral surface charge (Table 4).

Due to high polydispersity and low reproducibility of micelles obtained with F68, this polymer was discarded from the further studies. Regarding cytotoxicity assessment, both Pluronic ${ }^{\circledR}$ F108 and F127 presented $\mathrm{IC}_{50}$ higher than $10 \mathrm{mg} / \mathrm{mL}$ (Table 4). Because Pluronic ${ }^{\circledR}$ F127 micelles showed the smallest

A
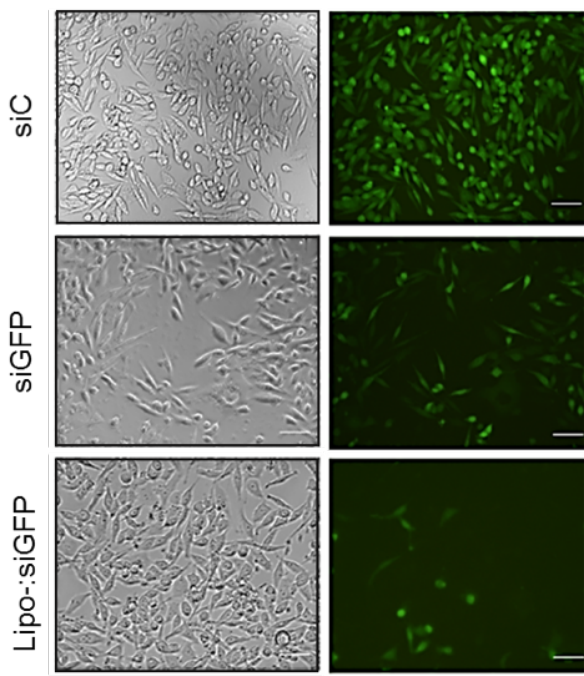

size and lowest polydispersity, it was selected to produce micelles combined with CL213-CSbased polyplexes (CS-siRNA-Pluronic ${ }^{\circledR}$ ). In the biological assessment, we observed better silencing of GFP expression from CS-siRNAPluronic ${ }^{\circledR}$-polyplexes compared to CSpolyplexes (Figure 2B). Conversely, no silencing was noticed in cells transfected with siC. However, despite the improvement in gene silencing promoted by the presence of Pluronic $^{\mathbb{B}}$ F127, silencing efficacy of this system is still lower than the one obtained using Lipofectamine ${ }^{\circledR} 2000$, as positive control.
B

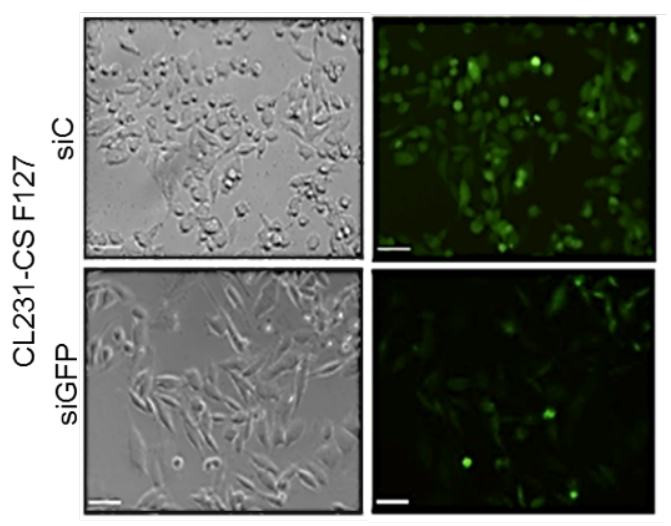

Figure 2. A, Silencing efficacy of CS-siRNA polyplexes at 72 hours after transfection in RXO-C cells expressing green fluorescent protein (GFP). Biological activity was assessed based on GFP expression reduction in cells transfected with CS polyplexes loaded with GFP-siRNA versus siC, using a fluorescence microscope. Lipofectamine ${ }^{\circledR} 2000$-based complexes were used as positive control. B, GFP silencing efficacy of CS-siRNA-Pluronic ${ }^{\circledR}$ micelles 72 hours post-transfection, using siGFP and siC in $R X O-C$ cells, respectively (results are expressed as mean $\pm S D, n=3$ ).

\section{PEl-based Systems: DM}

As cationic polymers, CS show advantages related with siRNA complexation efficiency and biological safety but fail in biological gene silencing efficacy. Therefore, the substitution of CS by PEI as cationic polymer was tested. Despite its potential cytotoxicity effects, PEI is also known for its endosomal membrane disruptive properties and high transfection ability. Pluronic ${ }^{\circledR}$ F127 PM were maintained as part of the formulation with the intention to reduce the required amount of PEI to obtain the desired biological effect, thus reducing PEIassociated toxicity (Table 5). 
Table 5. Summary of the Different Tested Conditions Regarding the Branched PEI-Based Systems

\begin{tabular}{|c|c|c|}
\hline \multicolumn{2}{|c|}{ Tested Conditions } & Observations \\
\hline $\begin{array}{l}\text { siRNA final conc. in the } \\
\text { well }\end{array}$ & $200 \mathrm{nM}$ & Effective (at certain conditions) \\
\hline \multirow{6}{*}{ Polymers combinations } & PEI 10K & Low effect \\
\hline & PEI 25K & Low effect \\
\hline & PEI 10K + F127 (0.5\%) & Effect $<$ than Lipofectamine ${ }^{\circledR} 2000$ \\
\hline & PEI $25 \mathrm{~K}+\mathrm{F} 127(0.5 \%)$ & Effect $<$ than Lipofectamine ${ }^{\circledR} 2000$ \\
\hline & PEI 10K + F127 (1\%) & Effective (at N/P 50) \\
\hline & PEI $25 \mathrm{~K}+\mathrm{F} 127(1 \%)$ & Effective (at N/P 25 and 50) \\
\hline \multirow{4}{*}{$\begin{array}{l}\mathrm{N} / \mathrm{P} \text { ratios } \\
\text { PEI:siRNA }\end{array}$} & 5 & No effect \\
\hline & 25 & Effective only for PEI $25 \mathrm{~K}$ \\
\hline & 50 & Effective \\
\hline & 75 & Toxic \\
\hline
\end{tabular}

Formulations composed by PEI:siRNA polyplexes of N/P ratio 50 presented higher transfection efficacy than polyplexes with lower N/P ratios (Figure 3A). No significant differences were observed between both types of PEI (Figure 3A). The 10K branched PEI. was chosen as cationic polymer because of its lower toxicity profile. ${ }^{46,47}$ As observed for CSpolyplexes, the presence of $1 \%$ Pluronic ${ }^{\circledR}$ F127 in the formation of micelles (prepared by DM) improved significantly the transfection efficiency of PEI-polyplexes (Figure 3B). Moreover, Pluronic ${ }^{\circledR}$ F127 reduces the cytotoxicity of PEI-polyplexes (Figure 4B).
Therefore, Pluronic ${ }^{\circledR} 127$ micelles associated with PEI:siRNA polyplexes at a N/P ratio 50 were selected for further studies, and characterized in terms of their internalization profile, physicochemical features and serum stability. The internalization of PEI-siRNAPluronic ${ }^{\circledR}$ micelles was qualitatively assessed by confocal microscopy (Figure 4A). For that, MDA-MB-231 cells were incubated with 5DTAF-labeled micelles for 4 hours. Internalization of PM was observed after incubation time, as well as co-localization with cytoplasmic endosomal vesicles (Figure 4A).
A

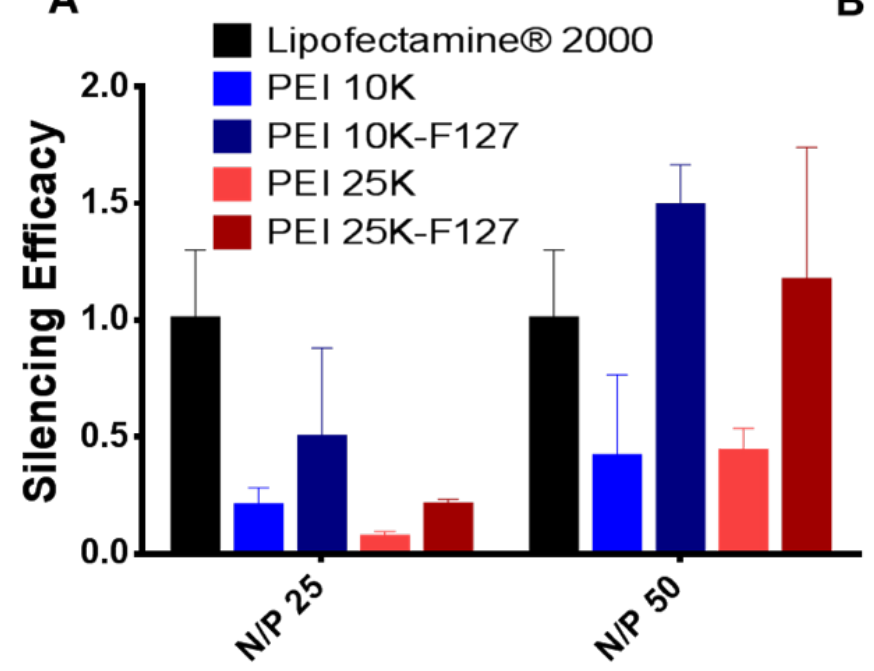

B

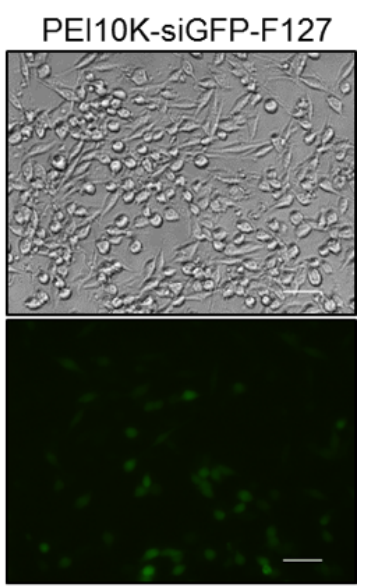

Figure 3. A, Green fluorescent protein (GFP) silencing efficacy of polyethylenimine (PEI)-siRNA polyplexes and PEI-siRNAPluronic ${ }^{\circledR}$ micelles (obtained by DM) in GFP expressing RXO-C cells. Lipofectamine ${ }^{\circledR} 2000$ was used as reference to determine differences on the intensity of GFP expression upon incubation with different formulations. GFP silencing values are normalized to Lipofectamine ${ }^{\circledR} 2000$ as control. Results are expressed as mean $\pm S D$ ( $\left.n \geq 3\right)$. $^{*} p \leq 0.05$ compared to the polyplexes without Pluronic ${ }^{\circledR}$ F127. B, Fluorescent microscopy of GFP silencing efficacy of PEI1OK-siGFP-F127 formulation. 
Despite the adequate association efficiency $(>93 \%)$, cytotoxicity $\left(\mathrm{IC}_{50}>10 \mathrm{mg} / \mathrm{mL}\right)$, and biological efficacy, the physicochemical characterization of this formulation showed increased polydispersity and aggregation over time, under storage. (Table 6). Moreover, serum stability studies showed an increase in the mean diameter of particles after the first 6 hours of incubation, clearly indicating their opsonization by serum proteins (Figure 4C).

Table 6. Physicochemical Characterization of PEI-siRNA-Pluronic ${ }^{\circledR}$ Micelles

\begin{tabular}{|l|l|l|l|l|}
\hline Sample & Md (nm) & PDI & ZP (mV) & AE (\%) \\
\hline PM-siRNA & $60.28 \pm 8.65$ & $0.51 \pm 0.07$ & $-0.21 \pm 0.06$ & $93.02 \pm 0.12$ \\
\hline PM & $73.22 \pm 9.54$ & $0.28 \pm 0.078$ & $3.81 \pm 0.96$ & \\
\hline
\end{tabular}

$\mathrm{AE}=$ association efficiency; $\mathrm{Md}=$ mean diameter; $\mathrm{PDI}=$ polydispersity index; $\mathrm{ZP}=\mathrm{zeta}$ potential. $\mathrm{AE}$ values are calculated by undirected method previously described. Results are expressed as mean $\pm \mathrm{SD}, \mathrm{n}=3$.

A
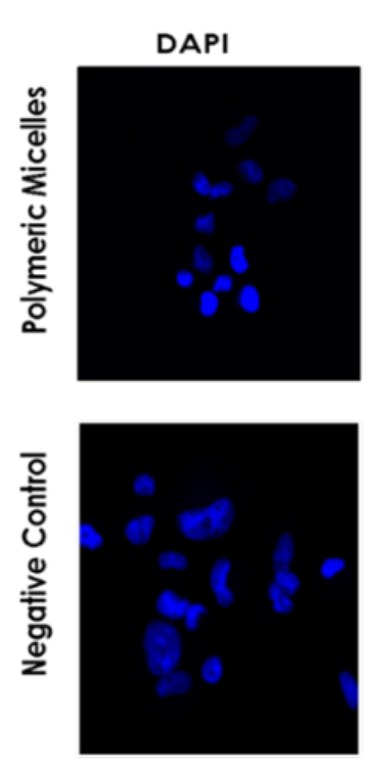

B

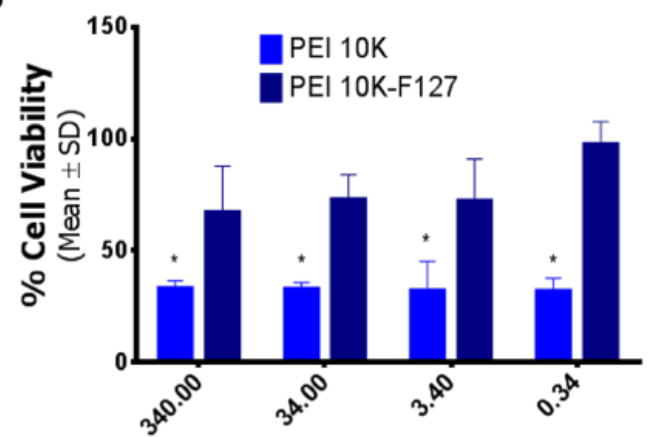

PEI concentration $(\mathrm{ng} / \mathrm{mL})$

Lysotracker
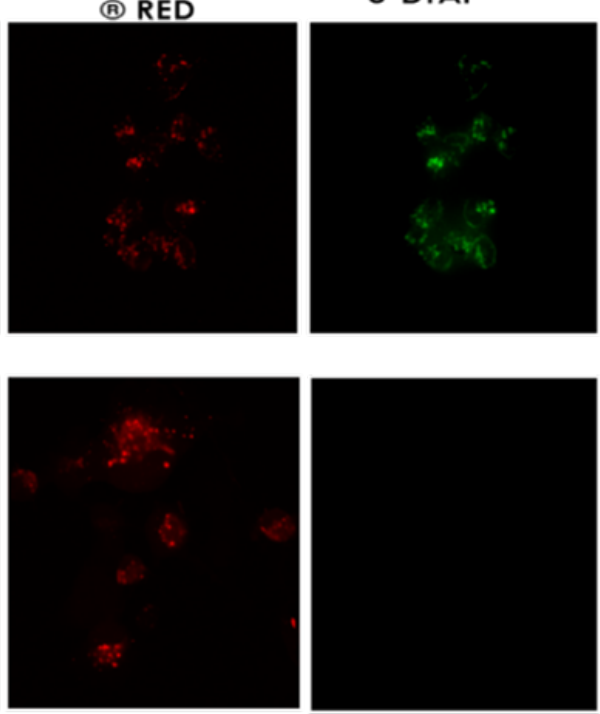

C

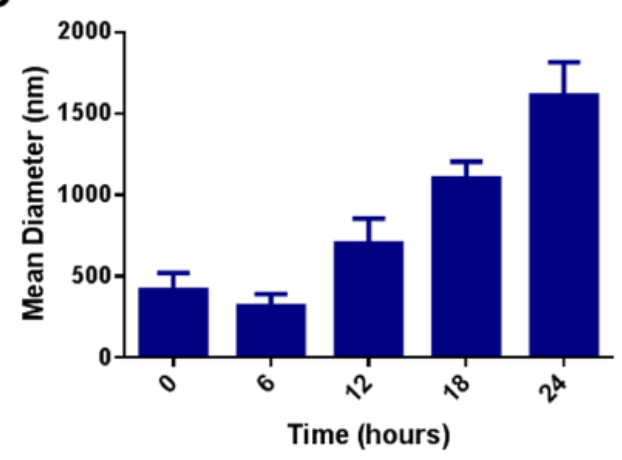

Figure 4. A, Comparative cytotoxicity of formulations with and without Pluronic ${ }^{\circ} \mathrm{F} 127$, at different concentrations. $B$, Confocal microscopy analysis of labelled particles. Internalization after 4 hours of incubation showing DAPI stained nuclei (blue), nanoparticles labelled with DTAF (green) and endocytic vesicles (Lysotracker [DND-99] red). C, Serum stability of PEI-siRNAPluronic ${ }^{\circ}$ formulation. The graphic shows mean diameter values of micelles after incubation with serum at different timepoints. Results are expressed as mean $\pm S D, n=3$. DAPI $=4,6$-diamidino-2-phenylindole; $D T A F=([4,6$-dichlorotriazin-2yl]amino) fluorescein hydrochloride; $P E I=$ polyethylenimine. 
Based on these results, it is possible to conclude that even though the combination of polymers in optimized ratios could be promising, unfortunately, the production method of PM by direct dissolution did not generate nanoparticles with adequate physicochemical features. The production of micelles by thin-FH technique was evaluated as an alternative, in order to improve their physicochemical characteristics.

\section{PEI-based Systems for siALOX5 Delivery,}

\section{as Model Gene: FH Technique}

Next, we generated a system for siRNA delivery combining (1) polyplexes formed by electrostatic interaction of negatively charged siRNA molecules and positively charged chains of PEI-10K, and (2) Pluronic ${ }^{\circledR}$ F127-based PM obtained by FH method, which yields better physicochemical characteristics (Figure 5A, Table 7).

Table 7. MD and PDI of loaded and unloaded formulations, as well as a loaded formulation stored 30 Days at $4^{\circ} \mathrm{C}$.

\begin{tabular}{|c|c|c|}
\hline Sample & $\begin{array}{c}\mathrm{Md}(\mathrm{nm}) \pm \\
\mathrm{SD}\end{array}$ & $\mathrm{PDI} \pm \mathrm{SD}$ \\
\hline PM-Empty & $\begin{array}{c}23.93 \pm \\
0.65\end{array}$ & $\begin{array}{c}0.250 \pm \\
0.007\end{array}$ \\
\hline PM-siALOX5 & $\begin{array}{c}24.51 \pm \\
0.53\end{array}$ & $\begin{array}{c}0.276 \pm \\
0.035\end{array}$ \\
\hline $\begin{array}{c}\text { PM-siALOX5 (30 } \\
\text { days) }\end{array}$ & $\begin{array}{c}27.72 \pm \\
1.16\end{array}$ & $\begin{array}{c}0.231 \pm \\
0.070\end{array}$ \\
\hline
\end{tabular}

$\mathrm{Md}=$ mean diameter; $\mathrm{PDI}=$ polydispersity index.

Results are expressed as mean $\pm \mathrm{SD}, \mathrm{n}=3$.
A

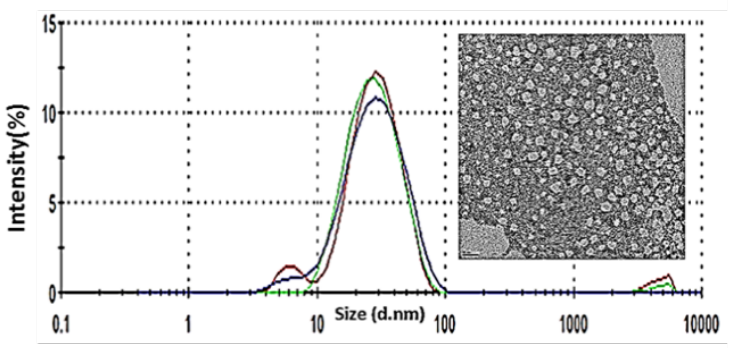

C

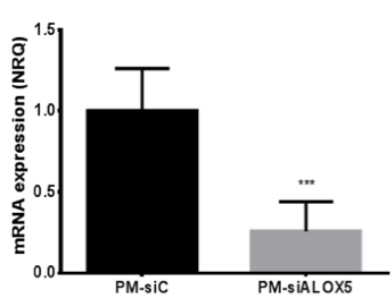

D

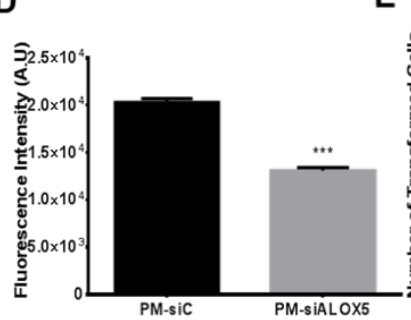

E
B
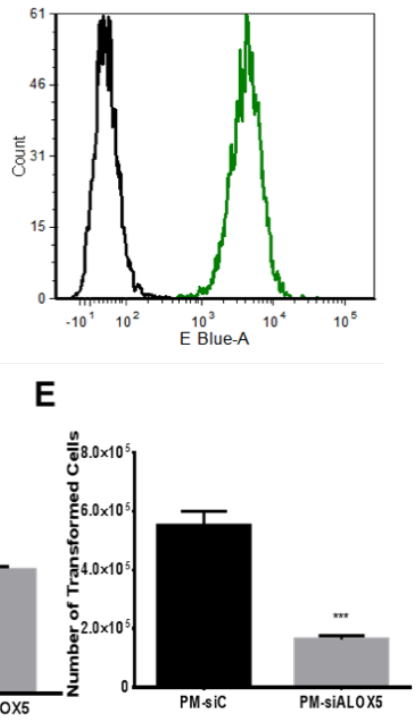

$\mathbf{F}$
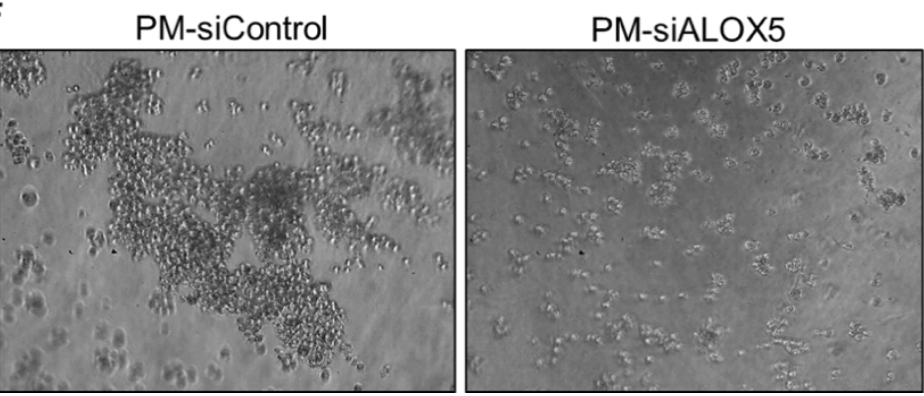

Figure 5. A, Physicochemical characterization of PM-siALOX5. B, Flow cytometry analysis of PEl-siRNA-Pluronic ${ }^{\circledR}$ internalization in MDA-MB-231 cells, after 4 hours of incubation with 5-DTAF labelled particles (green line). The black line corresponds to the negative control. C, ALOX5 downregulation in CSC population from the MDA-MB-231cell line after treatment with PM-siALOX5. ALOX5 expression was analyzed by qPCR. D, Invasion Assay: the number of invasive cells was quantified after 24 hours of incubation with PM-siC and PM-siALOX5 in MDA-MB-231 CSC. E, Transformation Assay: transformed cells were quantified after 8 days of incubation with PM-siC and PM-siALOX5 in MDA-MB-231ALDH1A1/tdTomato cell line. Pictures were taken at 10x in optical microscope and represent colonies formed within soft agar matrix after $a 7$ day of incubation. Results are expressed as mean $\pm \operatorname{SEM}(n=3),{ }^{* *} p \leq 0.001, * * p \leq 0.01,{ }^{*} p \leq 0.05$. 
ALOX5, a gene involved in CSC homeostasis was chosen as a model gene to test our siRNA system (siALOX5). PM-siALOX5 showed a Md value of $24 \mathrm{~nm}$ and a low PDI $(\leq 0.2)$. Moreover, after 30 days of storage no significant aggregation of particles was detected (Figure 5A, Table 7). Further, PM were easily internalized in MDA-MB-231 breast cancer cells with more than $98 \%$ of positive cells, after 4 hours of incubation (Figure 5B).

Biological efficacy of our system was also tested in breast CSC. PM-siALOX5 were transfected into CSC population isolated form MDA-MB-231 cell line. ALOX5 mRNA levels were quantified by qPCR. As shown in Figure $5 \mathrm{C}$ an encouraging significant silencing of ALOX5 expression was achieved. Furthermore, the effects of PM-siALOX5 transfection in CSC invasion and transformation capacity were also assessed. Accordingly, the invasive potential of breast CSC was significantly decreased $(p \leq 0.001)$ after transfection with PM-siALOX5 (Figure 5D), as well as their anchorage-independent growth ability (Figure 5E), showing that treatment with PM-siALOX5 reduced not only the number of transformed cells but also inhibits proper colony formation (Figure 5F).

\section{Discussion}

The present work aimed to develop an efficient and safe siRNA delivery system. Most gene delivery systems require the use of cationic components able to complex and condense genetic material, in order to facilitate their cellular internalization and biological effects (46-48). The use of cationic polymers however exhibit several drawbacks, particularly, exceeding levels of undesired toxicity. Because of this, different polymeric-based formulations were designed and tested overtime in order to select the best performing system with optimal characteristics for siRNA delivery. As a result, several formulations were discarded due to their toxicity and/or low biological efficacy. As shown, our first approach consisted in the complexation of siRNA in polyplexes composed by CS (CS-siRNA), a wellestablished biopolymer with recognized advantages in terms of gene delivery $(49,50)$.

Using Lipofectamine ${ }^{\circledR} 2000$ as positive control, different types of CS were tested at different conditions regarding concentration, $\mathrm{pH}$ and N/P ratio, in order to achieve the correct silencing efficacy/toxicity balance. RXO-C cells expressing GFP were used to test the silencing efficacy of polyplexes loaded with siRNA against GFP. Biological activity was assessed based on visual reduction of GFP expression in cells transfected with CS-siGFP versus CS-siC, using fluorescence microscopy. Regarding association efficiency of polyplexes, different polymer:siRNA ratios were also tested. As previously reported, our data also show the so well recognized capacity of CS to complex OGN, even at lower ratios $(51,52)$. Although a 1:2.5 ratio showed to be enough to complex siRNA, GFP reporter silencing assays demonstrate that in order to promote endosomal swelling and to obtain biological efficacy, higher polymer concentrations are required. This highlights that complexation is not the unique condition for the existence of biological effect, despite being essential for proper delivery of genetic material. In fact, N/P ratio proved to be an essential factor affecting complexation efficiency of polyplexes. Moreover, complexes formed at low molar ratio in the range of 2-5 tend to aggregate due to hydrophobic interactions, thus hampering its efficient transfection. In contrast, higher N/P ratios reduce aggregation as a result of electrostatic repulsion of higher positive surface charges of the complexes $(49,50)$. In agreement with this, an N/P ratio of 80 was required to observe biological efficacy, despite the low ratios required to ensure siRNA complexation.

According to our data, CS with higher MW presented the best results regarding transfection efficacy, which could be explained by its higher positive charge and capacity to better complex and protect siRNA. Similar data has been also provided by others using plasmids and siRNA (51-54). However, the biological efficacy observed with CS polyplexes showed to be insufficient. Although higher MW CS seem to better condense and protect siRNA for cellular delivery, it is possible that concurrent strong interactions of the system result in lower dissociation between $\mathrm{CS}$ and the genetic material after endosomal disruption, rendering low biological efficacy. As referred previously, it is of utmost importance to find a balance between MW and DD to efficiently complex 
and protect genetic material, promote its endosomal escape, and allow cytoplasmic release of OGN $(53,54)$.

In order to increase the biological efficacy, the most effective polyplex (CL213-CS) was posteriorly combined with Pluronic ${ }^{\circledR}$ micelles. This type of polymer has already been described as an enhancer of transfection of genetic material. Although not completely understood and explained, poloxamers interfere with cell membranes reducing their structure and microviscosity/fluidity and allowing escape from the endosomal compartment via membrane disruption and pore formation (55, 56). Different Pluronic ${ }^{\circledR}$ (F68, F108, F127) were tested, with Pluronic ${ }^{\circledR}$ F127 being the one selected due to its better technological features. The smaller size and PDI of F127-based micelles can be explained by their lower critical micellar concentration (CMC), hydrophiliclipophilic balance (HLB) and critical micellization temperature (CMT) $\left(24{ }^{\circ} \mathrm{C}\right.$ for $1 \%$ w/v solutions (57)), whereas $\mathrm{F} 68$ presents the highest CMC and CMT $\left(54-56.21{ }^{\circ} \mathrm{C}\right.$ for $1 \%$ $\mathrm{w} / \mathrm{v}$ solutions (58)) and consequently, higher diameter. Similar data has been reported previously (59). Further, poloxamers with intermediate HLB values like F127 (HLB=1823), have shown higher ability to interfere with membranes than poloxamers with higher HLB values like F68 and F108 (HLB>24) $(60,61)$. Thus, higher biological efficacy of the system containing Pluronic ${ }^{\circledR}$ F127 is expected.

Although the silencing efficiency of CS-based polyplexes appears to improve with the presence of Pluronic ${ }^{\circledR}$ F127 in the formulation, it is still substantially lower than those obtained with Lipofectamine ${ }^{\circledR} 2000$. Taking into account that the presence of Pluronic ${ }^{\circledR}$ improves the transfection efficiency of CS-based polyplexes, the substitution of $\mathrm{CS}$ for another cationic polymer, in this case PEI, was addressed. In order to rapidly screen different formulation compositions regarding their transfection efficiency, the reduction of GFP fluorescence in RXO-C/GFP expressing cells was quantified. Our data show that PEI-based polyplexes were able to reduce gene expression, being the transfection efficiency more significant for the polyplexes with an N/P ratio of 50 than N/P ratio 25 . Because no significant differences in terms of biological efficacy were observed between both types of PEI, the 10K branched
PEI was chosen due to its recognized lower toxicity profile (44). Interestingly, the presence of $1 \%$ Pluronic $^{\circledR}(\mathrm{w} / \mathrm{v})$ in the form of micelles improves significantly the transfection efficiency of the polyplexes as observed both, quantitatively and qualitatively by a higher GFP gene expression inhibition. The formulation where PEI 10k was complexed with siRNA at an N/P ratio of 50 and further incorporated into $1 \%(\mathrm{~m} / \mathrm{v})$ Pluronic ${ }^{\circledR}$ F127based PM, presented similar transfection efficacy and GFP silencing than Lipofectamine ${ }^{\circledR} 2000$. Contrarily to the need of complex chemical modifications proposed by other studies $(62,63)$, in this work we used a simple association of PEI-based polyplexes with Pluronic ${ }^{\circledR}$ F127-based PM. The micelles prepared by DM present the great advantage of being prepared by a simpler method, importantly avoiding the use of organic solvents. This is a relevant issue in terms of future translatability to the clinical practice. Unfortunately, higher sizes and polydispersity were shown, as well as lower reproducibility and stability, suffering aggregation in the presence of serum and also under storage. To overcome these technological drawbacks, we changed to the $\mathrm{FH}$ technique as production method (64). This method allowed the production of micelles with better physicochemical features (lower size $(<30 \mathrm{~nm})$ and PDI, as well as neutral zeta potential). A better control and more effective formation of micelles and association of PEI-polyplexes might explain this. Further, the importance of nanoparticles design for gene therapy is not only related with the condensation of genetic material but also with the prevention of its potential degradation. In our case, the particles obtained using the $\mathrm{FH}$ method present higher storage stability (64).

Oncology is certainly one of the fields that is most benefiting from the application of nanotechnology to drug and gene delivery. As a result of their malignant phenotype and resistance to conventional therapies, special attention has been given to CSC and to their specific targeting. An anti-CSC therapy, with a delivery system able to effectively reach them, is highly desirable. Otherwise, a reservoir of resistant CSC can cause recurrence and metastatic growth of a more aggressive form of cancer. In this work we used a CSC model we 
previously validated both in vitro and in vivo (42). To specifically target CSC, we selected siRNA against the gene ALOX5 as model gene. It has been shown that inhibition of ALOX5 is a promising strategy to hamper tumor development, due to its recognized role in CSC survival $(41,65,66)$. Our data show that PMsiALOX5 were quickly and effectively internalized in breast cancer cells and did not present significant toxicity in vitro for the working concentrations. We also confirmed that the presence of F127 was essential to reduce PEI-related cytotoxicity.

Downregulation of ALOX5 after treatment with PM-siALOX5 was studied by qPCR. A significant reduction of ALOX5 mRNA expression was observed. To study the effects of PM-siALOX5 on the metastatic potential of isolated $\mathrm{CSC}$, functional assays were performed. Interestingly, a significant impairment of CSC invasion capacity and anchorage-independent growth ability was observed. Cell neoplastic transformation and invasive potential are two important hallmarks for CSC aggressive behavior, thus the strategy of silencing ALOX5 using PEI10K-siALOX5F127 could be a promising and successful future antitumor therapy, particularly in advanced cancers.

In vivo toxicity of this formulation was tested through a maximum tolerated dose assay, and any change of body weight or any adverse effect was detected (64). This formulation was able to extravasate from blood circulation to the tumor mass (64). Moreover, with a F127 based delivery system with similar physicochemical features we assessed the biodistribution of the formulation in a breast cancer model and we obtained high percentages of tumor accumulation (10 to $15 \%$ ) mainly due to the enhanced permeability effect associated with the small size of the micelles (data not shown), which demonstrates the potentiality of these delivery systems in the field of cancer treatment.

\section{Conclusions}

In this work different cationic polymers were tested for the production of polyplexes and different polymeric systems. The choice of PM composed by Pluronic ${ }^{\circledR}$ F127 was based on their capacity to improve transfection efficiency of polyplexes and reduce toxicity. The amphiphilic properties of the system opened the possibility to design a multifunctional-targeted particle for combined therapies, such as a combination of gene- and chemotherapies in one single nanoparticle formulation. Two different PM preparation methods were also compared. The DM technique was the easiest and less timeconsuming method to prepare micelles and avoid organic solvents; however, it had important disadvantages regarding the technological features when compared with micelles obtained by the FH technique. Finally, a promising vehicle with adequate physicochemical and biological properties for gene delivery (siRNA-ALOX5) was selected after screening different formulations. Following the concept of precision nanomedicine, the effective gene silencing of our system opens the door to design better gene delivery strategies to specifically target cancer genes, and therefore, benefit specific groups of patients according to their cancer type or genetic profiles.

\section{Acknowledgments}

This work was partially supported by grants PI14/02079 and PI17/02242 from Fondo de Investigaciones Sanitarias (FIS) of Instituto Carlos III (ISCIII), co-financed by the European Regional Development Fund (FEDER), and grant AC15/00092 (Target4Cancer project) from EuroNanoMed II to SS and grant 337/C/2013 (PENTRI project) from Fundació Marató TV3 (Catalonia, Spain) to IA. This study was also supported by the Portuguese Science and Technology Foundation (FCT) (PTDC/SAUFAR/120453/2010) and in part, by iMed.ULisboa, Portugal (UID/DTP/04138/2013). FCT supported DR with a predoctoral grant (SFRH/BD/76270/2011) and the Spanish Asociación Española Contra el Cáncer (AECC) supported JSF with a postdoctoral fellowship.

\section{Conflict of Interest}

The authors declare no conflicts of interest. For signed statements, please contact the journal office: editor@precisionnanomedicine.com 
Quote this article as: Rafael D, Andrade F, Montero S, Gener P, Seras-Franzoso J, Martínez F, González P, Florindo H, Arango D, Sayós J, Abasolo I, Videira M, and Schwartz Jr. S. Rational Design of a siRNA Delivery System: ALOX5 and Cancer Stem Cells as Therapeutic Targets, Precis. Nanomed. 2018;1(2):86-105, https://doi.org/10.29016/180629.1

\section{Bibliography}

1. Wang D, Gao G. State-of-the-art human gene therapy: Part I. gene delivery technologies. Discov Med. 2014;18(97):67-77. PubMed PMID: 25091489; PubMed Central PMCID: PMC4440413.

2. Li L, Wei Y, Gong C. Polymeric Nanocarriers for Non-Viral Gene Delivery. J Biomed Nanotechnol. 2015;11(5):739-70. PubMed PMID: 26349389.

3. Kaufmann KB, Büning H, Galy A, Schambach A, Grez M. Gene therapy on the move. EMBO Mol Med. 2013;5(11):1642-61. doi: 10.1002/emmm.201202287. PubMed PMID: 24106209; PubMed Central PMCID: PMC3840483.

4. Videira M, Arranja A, Rafael D, Gaspar R. Preclinical development of siRNA therapeutics: towards the match between fundamental science and engineered systems. Nanomedicine. 2014;10(4):689-702. doi: 10.1016/j.nano.2013.11.018. PubMed PMID: 24333589.

5. Wasungu L, Hoekstra D. Cationic lipids, lipoplexes and intracellular delivery of genes. J Control Release. 2006;116(2):255-64. doi: 10.1016/j.jconrel.2006.06.024. PubMed PMID: 16914222. 6. Eliyahu H, Joseph A, Schillemans JP, Azzam T, Domb AJ, Barenholz Y. Characterization and in vivo performance of dextran-spermine polyplexes and DOTAP/cholesterol lipoplexes administered locally and systemically. Biomaterials. 2007;28(14):2339-49. doi: 10.1016/j.biomaterials.2006.09.001. PubMed PMID: 17298842.

7. Chira S, Jackson CS, Oprea I, Ozturk F, Pepper MS, Diaconu I, et al. Progresses towards safe and efficient gene therapy vectors. Oncotarget. 2015;6(31):30675-703. PubMed PMID: 26362400; PubMed Central PMCID: PMC4741561.

8. Xiong XB, Falamarzian A, Garg SM, Lavasanifar A. Engineering of amphiphilic block copolymers for polymeric micellar drug and gene delivery. J Control Release. 2011;155(2):248-61. doi: S0168-3659(11)00243-4 [pii] 10.1016/j.jconrel.2011.04.028. PubMed PMID: 21621570.

9. Ozpolat B, Sood AK, Lopez-Berestein G. Nanomedicine based approaches for the delivery of siRNA in cancer. Journal of internal medicine. 2010;267(1):44-53. Epub 2010/01/12. doi: 10.1111/j.1365-2796.2009.02191.x. PubMed PMID: 20059643.

10. Dizaj SM, Jafari S, Khosroushahi AY. A sight on the current nanoparticle-based gene delivery vectors. Nanoscale Res Lett. 2014;9(1):252. doi: 10.1186/1556-276X-9-252. PubMed PMID: 24936161; PubMed Central PMCID: PMCPMC4046008.

11. Nayerossadat N, Maedeh T, Ali PA. Viral and nonviral delivery systems for gene delivery. Adv Biomed Res. 2012;1:27. doi: 10.4103/2277-9175.98152. PubMed PMID: 23210086; PubMed Central PMCID: PMCPMC3507026.

12. Mao S, Sun W, Kissel T. Chitosan-based formulations for delivery of DNA and siRNA. Adv Drug Deliv Rev. 2010;62(1):12-27. doi: S0169-409X(09)00281-6 [pii]

10.1016/j.addr.2009.08.004. PubMed PMID: 19796660.

13. Rudzinski WE, Aminabhavi TM. Chitosan as a carrier for targeted delivery of small interfering RNA. Int J Pharm. 2010;399(1-2):1-11. doi: S0378-5173(10)00627-7 [pii] 10.1016/j.ijpharm.2010.08.022. PubMed PMID: 20732398.

14. Holzerny P, Ajdini B, Heusermann W, Bruno K, Schuleit M, Meinel L, et al. Biophysical properties of chitosan/siRNA polyplexes: profiling the polymer/siRNA interactions and bioactivity. $\mathrm{J}$ Control Release. 2012;157(2):297-304. doi: 10.1016/j.jconrel.2011.08.023. PubMed PMID: 21884740 .

15. Park IK, Park YH, Shin BA, Choi ES, Kim YR, Akaike T, et al. Galactosylated chitosangraft-dextran as hepatocyte-targeting DNA carrier. J Control Release. 2000;69(1):97-108. PubMed PMID: 11018549. 
16. Kim TH, Ihm JE, Choi YJ, Nah JW, Cho CS. Efficient gene delivery by urocanic acidmodified chitosan. J Control Release. 2003;93(3):389-402. PubMed PMID: 14644588.

17. Kim TH, Kim SI, Akaike T, Cho CS. Synergistic effect of poly(ethylenimine) on the transfection efficiency of galactosylated chitosan/DNA complexes. J Control Release.

2005;105(3):354-66. doi: S0168-3659(05)00133-1 [pii]

10.1016/j.jconrel.2005.03.024. PubMed PMID: 15949861.

18. Wong K, Sun G, Zhang X, Dai H, Liu Y, He C, et al. PEI-g-chitosan, a novel gene delivery system with transfection efficiency comparable to polyethylenimine in vitro and after liver administration in vivo. Bioconjug Chem. 2006;17(1):152-8. doi: 10.1021/bc0501597.

19. Lin A, Liu Y, Huang Y, Sun J, Wu Z, Zhang X, et al. Glycyrrhizin surface-modified chitosan nanoparticles for hepatocyte-targeted delivery. Int J Pharm. 2008;359(1-2):247-53. doi:

10.1016/j.ijpharm.2008.03.039. PubMed PMID: 18457928.

20. Gabizon A, Shmeeda H, Horowitz AT, Zalipsky S. Tumor cell targeting of liposomeentrapped drugs with phospholipid-anchored folic acid-PEG conjugates. Adv Drug Deliv Rev. 2004;56(8):1177-92. doi: 10.1016/j.addr.2004.01.011. PubMed PMID: 15094214.

21. Moreira C, Oliveira H, Pires LR, Simões S, Barbosa MA, Pêgo AP. Improving chitosanmediated gene transfer by the introduction of intracellular buffering moieties into the chitosan backbone. Acta Biomater. 2009;5(8):2995-3006. doi: S1742-7061(09)00176-7 [pii]

10.1016/j.actbio.2009.04.021. PubMed PMID: 19427930.

22. Akinc A, Thomas M, Klibanov AM, Langer R. Exploring polyethylenimine-mediated DNA transfection and the proton sponge hypothesis. J Gene Med. 2005;7(5):657-63. doi: 10.1002/jgm.696. PubMed PMID: 15543529.

23. Roesler S, Koch FP, Schmehl T, Weissmann N, Seeger W, Gessler T, et al. Amphiphilic, low molecular weight poly(ethylene imine) derivatives with enhanced stability for efficient pulmonary gene delivery. J Gene Med. 2011;13(2):123-33. doi: 10.1002/jgm.1538. PubMed PMID: 21308899. 24. Martin I, Dohmen C, Mas-Moruno C, Troiber C, Kos P, Schaffert D, et al. Solid-phaseassisted synthesis of targeting peptide-PEG-oligo(ethane amino)amides for receptor-mediated gene delivery. Org Biomol Chem. 2012;10(16):3258-68. doi: 10.1039/c2ob06907e.

25. Godbey WT, Wu KK, Mikos AG. Size matters: molecular weight affects the efficiency of poly(ethylenimine) as a gene delivery vehicle. J Biomed Mater Res. 1999;45(3):268-75. PubMed PMID: 10397985.

26. Thomas M, Klibanov AM. Enhancing polyethylenimine's delivery of plasmid DNA into mammalian cells. Proc Natl Acad Sci U S A. 2002;99(23):14640-5. doi: 10.1073/pnas.192581499. PubMed PMID: 12403826; PubMed Central PMCID: PMCPMC137472.

27. Mao S, Neu M, Germershaus O, Merkel O, Sitterberg J, Bakowsky U, et al. Influence of polyethylene glycol chain length on the physicochemical and biological properties of poly(ethylene imine)-graft-poly(ethylene glycol) block copolymer/SiRNA polyplexes. Bioconjug Chem. 2006;17(5):1209-18. doi: 10.1021/bc060129j. PubMed PMID: 16984130.

28. Dehshahri A, Oskuee RK, Shier WT, Hatefi A, Ramezani M. Gene transfer efficiency of high primary amine content, hydrophobic, alkyl-oligoamine derivatives of polyethylenimine. Biomaterials. 2009;30(25):4187-94. doi: 10.1016/j.biomaterials.2009.04.036. PubMed PMID: 19464054.

29. Grayson AC, Doody AM, Putnam D. Biophysical and structural characterization of polyethylenimine-mediated siRNA delivery in vitro. Pharm Res. 2006;23(8):1868-76. doi: 10.1007/s11095-006-9009-2. PubMed PMID: 16845585.

30. Oskuee RK, Philipp A, Dehshahri A, Wagner E, Ramezani M. The impact of carboxyalkylation of branched polyethylenimine on effectiveness in small interfering RNA delivery. $\mathrm{J}$ Gene Med. 2010;12(9):729-38. Epub 2010/08/05. doi: 10.1002/jgm.1490. PubMed PMID: 20683834. 31. Malek A, Czubayko F, Aigner A. PEG grafting of polyethylenimine (PEI) exerts different effects on DNA transfection and siRNA-induced gene targeting efficacy. Journal of Drug Targeting. 2008;16(2):124-39. Epub 2008/02/16. doi: 10.1080/10611860701849058. PubMed PMID: 18274933. 32. Moghimi SM, Hunter AC. Poloxamers and poloxamines in nanoparticle engineering and experimental medicine. Trends Biotechnol. 2000;18(10):412-20. doi: S0167-7799(00)01485-2 [pii]. PubMed PMID: 10998507. 
33. Kabanov AV, Batrakova EV, Alakhov VY. Pluronic block copolymers as novel polymer therapeutics for drug and gene delivery. J Control Release. 2002;82(2-3):189-212. doi: S0168365902000093 [pii]. PubMed PMID: 12175737.

34. Batrakova EV, Kabanov AV. Pluronic block copolymers: evolution of drug delivery concept from inert nanocarriers to biological response modifiers. J Control Release. 2008;130(2):98-106. doi: 10.1016/j.jconrel.2008.04.013. PubMed PMID: 18534704; PubMed Central PMCID: PMCPMC2678942.

35. Chen YC, Jiang LP, Liu NX, Ding L, Liu XL, Wang ZH, et al. Enhanced gene transduction into skeletal muscle of mice in vivo with pluronic block copolymers and ultrasound exposure. Cell Biochem Biophys. 2011;60(3):267-73. doi: 10.1007/s12013-010-9149-1. PubMed PMID: 21253893. 36. Wang F, Li K, Chen Y. Gene transfection mediated by ultrasound and Pluronic P85 in HepG2 cells. J Huazhong Univ Sci Technolog Med Sci. 2007;27(6):700-2. doi: 10.1007/s11596-007-0621-0. PubMed PMID: 18231747.

37. Kabanov A, Zhu J, Alakhov V. Pluronic block copolymers for gene delivery. Advances in genetics. 2005;53:231-61. Epub 2005/10/26. PubMed PMID: 16240996.

38. Wang M, Wu B, Lu P, Tucker JD, Milazi S, Shah SN, et al. Pluronic-PEI copolymers enhance exon-skipping of 2'-O-methyl phosphorothioate oligonucleotide in cell culture and dystrophic mdx mice. Gene Ther. 2014;21(1):52-9. doi: 10.1038/gt.2013.57.

39. Kuo JH. Effect of Pluronic-block copolymers on the reduction of serum-mediated inhibition of gene transfer of polyethyleneimine-DNA complexes. Biotechnol Appl Biochem. 2003;37(Pt 3):267-71. doi: BA20020123 [pii] 10.1042/BA20020123. PubMed PMID: 12597775.

40. Yang F, Xu J, Tang L, Guan X. Breast cancer stem cell: the roles and therapeutic implications. Cellular and molecular life sciences : CMLS. 2017;74(6):951-66. doi: 10.1007/s00018016-2334-7. PubMed PMID: 27530548.

41. Chen Y, Shan Y, Lu M, DeSouza N, Guo Z, Hoffman R, et al. Alox5 Blockade Eradicates JAK2V617F-Induced Polycythemia Vera in Mice. Cancer research. 2017;77(1):164-74. doi: 10.1158/0008-5472.CAN-15-2933. PubMed PMID: 27784744; PubMed Central PMCID: PMC5217717.

42. Gener P, Gouveia LP, Sabat GR, de Sousa Rafael DF, Fort NB, Arranja A, et al. Fluorescent CSC models evidence that targeted nanomedicines improve treatment sensitivity of breast and colon cancer stem cells. Nanomedicine. 2015;11(8):1883-92. doi: 10.1016/j.nano.2015.07.009. PubMed PMID: 26238079.

43. Andrade F, das Neves J, Gener P, Schwartz S, Ferreira D, Oliva M, et al. Biological assessment of self-assembled polymeric micelles for pulmonary administration of insulin. Nanomedicine. 2015;11(7):1621-31. doi: 10.1016/j.nano.2015.05.006. PubMed PMID: 26049134. 44. Paul A, Eun C-J, Song JM. Cytotoxicity mechanism of non-viral carriers polyethylenimine and poly-1-lysine using real time high-content cellular assay. Polymer. 2014;55(20):5178-88. 45. Symonds P, Murray JC, Hunter AC, Debska G, Szewczyk A, Moghimi SM. Low and high molecular weight poly(L-lysine)s/poly(L-lysine)-DNA complexes initiate mitochondrial-mediated apoptosis differently. FEBS Lett. 2005;579(27):6191-8. doi: 10.1016/j.febslet.2005.09.092.

46. Tros de Ilarduya C, Sun Y, Düzgüneş N. Gene delivery by lipoplexes and polyplexes. Eur J Pharm Sci. 2010;40(3):159-70. doi: 10.1016/j.ejps.2010.03.019. PubMed PMID: 20359532.

47. Iyer AK, Duan Z, Amiji MM. Nanodelivery systems for nucleic acid therapeutics in drug resistant tumors. Molecular pharmaceutics. 2014;11(8):2511-26. Epub 2014/03/26. doi: 10.1021/mp500024p. PubMed PMID: 24661041.

48. Rafael DF, Andrade F, Arranja A, Luís AS, Videira M. Lipoplexes and Polyplexes: Gene Delivery Applications. Encyclopedia Biomedical Polymers and Polymeric Biomaterials, Taylor and Francis Group 2014.

49. Huang M, Fong CW, Khor E, Lim LY. Transfection efficiency of chitosan vectors: effect of polymer molecular weight and degree of deacetylation. J Control Release. 2005;106(3):391-406. doi: S0168-3659(05)00232-4 [pii]

10.1016/j.jconrel.2005.05.004. PubMed PMID: 15967533. 
50. Lavertu M, Méthot S, Tran-Khanh N, Buschmann MD. High efficiency gene transfer using chitosan/DNA nanoparticles with specific combinations of molecular weight and degree of deacetylation. Biomaterials. 2006;27(27):4815-24. doi: 10.1016/j.biomaterials.2006.04.029.

51. Mao S, Sun W, Kissel T. Chitosan-based formulations for delivery of DNA and siRNA. Adv Drug Deliv Rev. 2010;62(1):12-27. doi: 10.1016/j.addr.2009.08.004. PubMed PMID: 19796660.

52. Rudzinski WE, Aminabhavi TM. Chitosan as a carrier for targeted delivery of small interfering RNA. International journal of pharmaceutics. 2010;399(1-2):1-11. Epub 2010/08/25. doi: 10.1016/j.ijpharm.2010.08.022. PubMed PMID: 20732398.

53. Köping-Höggård M, Tubulekas I, Guan H, Edwards K, Nilsson M, Vårum KM, et al. Chitosan as a nonviral gene delivery system. Structure-property relationships and characteristics compared with polyethylenimine in vitro and after lung administration in vivo. Gene Ther. 2001;8(14):1108-21. doi: 10.1038/sj.gt.3301492. PubMed PMID: 11526458.

54. Köping-Höggård M, Vårum KM, Issa M, Danielsen S, Christensen BE, Stokke BT, et al. Improved chitosan-mediated gene delivery based on easily dissociated chitosan polyplexes of highly defined chitosan oligomers. Gene Ther. 2004;11(19):1441-52. doi: 10.1038/sj.gt.3302312.

55. Demina T, Grozdova I, Krylova O, Zhirnov A, Istratov V, Frey H, et al. Relationship between the structure of amphiphilic copolymers and their ability to disturb lipid bilayers. Biochemistry. 2005;44(10):4042-54. doi: 10.1021/bi048373q. PubMed PMID: 15751981.

56. Batrakova EV, Li S, Alakhov VY, Miller DW, Kabanov AV. Optimal structure requirements for pluronic block copolymers in modifying P-glycoprotein drug efflux transporter activity in bovine brain microvessel endothelial cells. The Journal of pharmacology and experimental therapeutics. 2003;304(2):845-54. Epub 2003/01/23. doi: 10.1124/jpet.102.043307. PubMed PMID: 12538842. 57. Lin Y, Alexandridis P. Temperature-dependent adsorption of Pluronic F127 block copolymers onto carbon black particles dispersed in aqueous media. J Phys Chem B. 2002;106:10834-44.

58. Tsui H-W, Wang J-H, Hsu Y-H, Chen L-J. Study of heat of micellization and phase separation for Pluronic aqueous solutions by using a high sensitivity differential scanning calorimetry. Colloid and Polymer Science. 2010;288:1687-96.

59. Andrade F, Fonte P, Oliva M, Videira M, Ferreira D, Sarmento B. Solid state formulations composed by amphiphilic polymers for delivery of proteins: characterization and stability. International Journal of Pharmaceutics. 2015;486(1-2):195-206. doi: 10.1016/j.ijpharm.2015.03.050.

60. Chen J, Luo J, Zhao Y, Pu L, Lu X, Gao R, et al. Increase in transgene expression by pluronic L64-mediated endosomal/lysosomal escape through its membrane-disturbing action. ACS applied materials \& interfaces. 2015;7(13):7282-93. Epub 2015/03/20. doi: 10.1021/acsami.5b00486. 61. Katas H, Alpar HO. Development and characterisation of chitosan nanoparticles for siRNA delivery. J Control Release. 2006;115(2):216-25. doi: 10.1016/j.jconrel.2006.07.021.

62. Hu Y, Zhou D, Li C, Zhou H, Chen J, Zhang Z, et al. Gene delivery of PEI incorporating with functional block copolymer via non-covalent assembly strategy. Acta biomaterialia. 2013;9(2):500312. Epub 2012/10/06. doi: 10.1016/j.actbio.2012.09.033. PubMed PMID: 23036947.

63. Wen Y, Pan S, Luo X, Zhang W, Shen Y, Feng M. PEG- and PDMAEG-graft-modified branched PEI as novel gene vector: synthesis, characterization and gene transfection. Journal of biomaterials science Polymer edition. 2010;21(8-9):1103-26. Epub 2010/05/29. doi:

10.1163/092050609X12459295750316. PubMed PMID: 20507711.

64. Rafael D, Gener P, Andrade F, Seras-Franzoso J, Montero S, Fernandez Y, et al. AKT2 siRNA delivery with amphiphilic-based polymeric micelles show efficacy against cancer stem cells. Drug delivery. 2018;25(1):961-72. doi: 10.1080/10717544.2018.1461276. PubMed PMID: 29667444. 65. Chen Y, Li D, Li S. The Alox5 gene is a novel therapeutic target in cancer stem cells of chronic myeloid leukemia. Cell cycle. 2009;8(21):3488-92. doi: 10.4161/cc.8.21.9852.

66. Chen Y, Hu Y, Zhang H, Peng C, Li S. Loss of the Alox5 gene impairs leukemia stem cells and prevents chronic myeloid leukemia. Nature genetics. 2009;41(7):783-92. doi: 10.1038/ng.389. PubMed PMID: 19503090; PubMed Central PMCID: PMC2887745. 